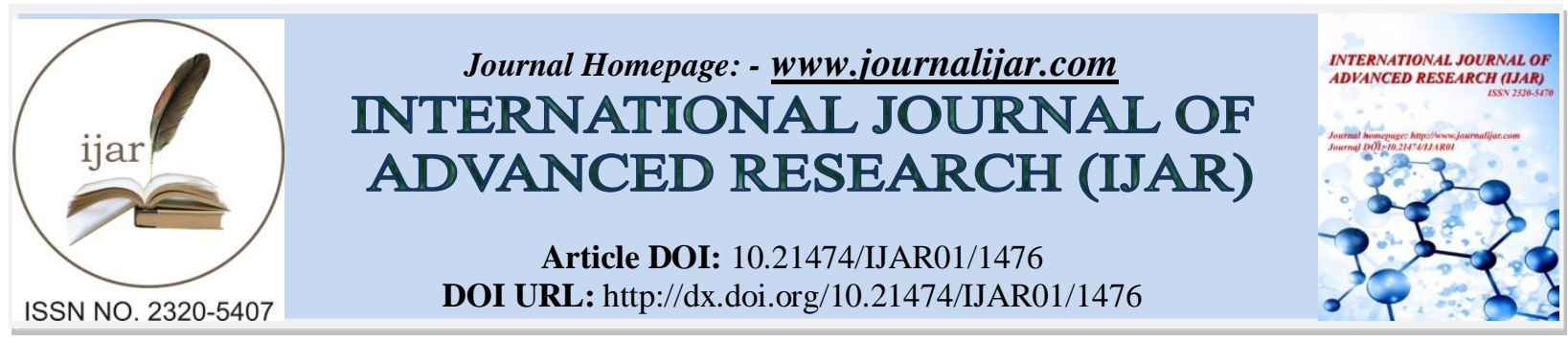

RESEARCH ARTICLE

\title{
ICT IN FINANCIAL INCLUSION.
}

\section{Dr. J. Chithralega ${ }^{1}$ and Dr. G. Varalakshmi ${ }^{2}$.}

1. Assistant professor, Department of Commerce, Anna Adarsh College for women, Anna Nagar, Chennai.

2. Assistant professor, Department of Corporate Secretaryship, Anna Adarsh College for women, Anna Nagar, Chennai.

\section{Manuscript Info \\ Manuscript History \\ Received: 12 July 2016 \\ Final Accepted: 19 August 2016 \\ Published: September 2016}

Key words:-

financial inclusion, ICT.

\section{Abstract}

The purpose of this paper is to examine the role of information communication technology in financial inclusion. To pull millions of Indians out of poverty, inclusive growth is extremely necessary by covering large population of India with financial services. Financial inclusion is a crucial driver for such growth. Many efforts have been made to achieve the objectives of the financial inclusion and one such effort is adoption of ICT in banking sector. The role of Information Technology can be realized from the fact that it has greater population penetration and its ability to serve in remote location at low cost which is essential requirement for Financial Inclusion. According to the index of Crisil Inclusix 2013, among the various districts in Tamil $\mathrm{Nadu}$, Coimbatore is the top scorer of financial inclusion and next comes Chennai in all four years.

Copy Right, IJAR, 2016,. All rights reserved.

\section{Introduction:-}

The economic liberalisation in 1991 and the high growth of GDP at 10.1 in 2010 have led to financial exclusion. To negate this inequality it was understood that inclusive growth is necessary. As financial exclusion is much higher in India, the efforts for financial inclusion are much more important. Financial inclusion aims to deliver financial services to all the people in a fair, transparent and equitable manner at an affordable cost as well as making latest technologies available in these areas is also one of the prerequisites for overall development of our country. Technologies have not only changed the way we communicate, but have also become the driving force of changes in the modern world. ICT may be defined as the technology that facilitates collection, transfer and transformation of data $\&$ knowledge, in a manner more efficient, faster and productive. This is essential for an inclusive growth and towards eradicating poverty.

\section{Area of concern for financial inclusion:-}

Banks provide services through their branches and opening of a branch at every village is not feasible and viable due to the inadequate power supply and non-availability of digital network. Financially excluded groups are from poor, under privileged social group, disabled, old as well as children, women, uneducated and ethnic minorities. To reach such groups at their residence or work place, door step banking through cost effective technology driven model, together with Business correspondents/ Business facilitator with the use of technology will provide the desired result. The model will be successful only if it has the acceptability and confidence of the rural people.

Corresponding Author:- Dr. J. Chithralega.

Address:- Assistant professor, Department of Commerce, Anna Adarsh College for women, Anna 
The bank which has ability to finance, accounting with the Business correspondent and Business facilitator has a better ability to increase the outreach of financial inclusion initiatives. The model will uplift the socially and financially excluded poor thus benefiting the society as a whole. The little drops of savings of poor will be brought into the banking to add up to ocean. Credit counselling is essential to make sure that the farmers in the remote areas are successful. Information relating to credit facilities available in the bank must be informed to meet out various needs of the farmer. The BC and BF plays an important role in the dispersal of the credit schemes and enable them to choose from the various options. With the advancement of technology, a person in a remote area should be able to access his accounts, avail his credit limits with the use of only one card which should also double up as his multipurpose bio-metric enabled identity card.

\section{Factors Affecting Access to Financial Services:-}

Following are factors that affect access to financial services which have been identified in many countries:

Gender issues:- Mostly women do not have easy access to credit who do not have, or cannot hold title to assets or must seek male guarantees to borrow.

Age factor:- Financial service providers generally aim the middle of the economically active population and not older or younger potential customers.

Legal identity:- Women, ethnic minorities, economic and political refugees and migrant workers are often excluded from having access to financial services due to lack of legal identities like identity cards, birth certificates or written records often exclude

Limited literacy:- Lack of financial literacy, i.e., basic mathematics, business finance skill often constrains demand for financial services.

Place of living:- Lack of transportation facilities as physical distance, factors like density of population, rural, remote areas and highly mobile people with no fixed or formal address also affect access to financial services.

Psychological and cultural barriers:- The low income groups generally have a feeling that banks are not interested to look into their cause has led to self-exclusion. In some of the countries cultural and religious barriers to banking have also been observed as reasons for exclusion.

Social security payments:- Financial exclusion is greater in those countries where the social security payment system is not linked to the banking system.

Bank charges:- These charges have an uneven effect on low income people. In many countries, transaction is free as long as the account has sufficient funds to cover the cost of transactions made.

Terms and conditions:- Terms and conditions attached to provision of financial service such as minimum balance requirements and conditions relating to the use of accounts often discourage people from using such products or services.

Level of income:- The poorer members of the community are excluded from access to financial services even when the services are tailored for them, they find it difficult.

Attractiveness of the product:- Marketing of the availability of both the financial services and products (savings accounts, credit products, payment services and insurance) are vital in financial inclusion.

\section{Review of literature:-}

Mohan (2008) has stated that the Reserve Bank of India focuses on growth and inflation in many developing countries. The priority of RBI since 2004 has been to provide access to the large number of people.

Oya Pinar Ardic et al (2011) have explained that there is yet much to be done in the financial inclusion arena. Fifty-six percent of adults in the world do not have access to formal financial services. 
CRISIL (2013) This is an index that measures the extent of financial inclusion in India using non-monetary aggregates. The CRISIL Inclusix parameters are based on the number of individuals having access to various financial services rather than focusing on the loan amount. Branch, deposit and credit penetration are the three parameters of the index which were updated annually and based on the availability of data, additional services being insurance and microfinance. It was found that one in two Indians has a savings account and only one in seven Indians have access to banking credit. CRISIL has provided all information regarding the progress of financial inclusion in rural and in urban areas in the country.

RBI (2014) has focused on achieving the goal of maximum financial inclusion and increased access to financial inclusion. The committee proposed the following measures: provision of electronic bank account, Electronic Payment Access Points for easy deposit and withdrawal facilities, provision of credit products, investment and deposit products, insurance and risk management products by formal institutions. It was found that the majority of small business organisations were operating without the help of formal financial institutions and more than half of the urban and rural population did not have access to bank account as well as savings. The recommendation of the committee was that each individual should have Universal Electronic Bank Account while registering for an Aadhar card. It was further recommended that banks should purchase portfolio insurance which will help in managing their credit exposures. A State Finance Regulatory Commission where all the state level financial regulators will work together was also recommended.

\section{Objective:-}

- To throw light on the measures taken by the Government and RBI for promoting financial inclusion

- To highlight the role of technology in financial inclusion

- To provide information on the status of financial inclusion in Tamil Nadu

\section{Methodology:-}

Secondary research was conducted to review the present status of financial inclusion in India. The data was collected from secondary sources such as journals, published articles and websites of RBI and report of various committees submitted to the Government as well as from Crisil Inclusix Index.

Initiatives of the Government and the Reserve Bank:-

The Government and the Reserve Bank have taken several initiatives to bring the poor and weaker sections of the society within the banking fold to have a favourable impact. On the other hand, still an ample portion of the rural and urban low income population, mainly the immigrant labour, has very little access to financial services where the extent of the problem is huge. These groups pay a high interest for accessing credit from moneylenders and other informal sources. Therefore, it is necessary to expand the outreach of financial system to include rural and poor people.

- Government had issued detailed guidelines on October 2011 and advising banks to open branches in all habitation of 5,000 or more population in under banked districts and 10,000 or more population in other districts.

- Swabhimaan Campaign was launched on February 2011, Banks had provided banking facilities by March 2012 to more than 74,000 habitations, having population in excess of 2,000 using various models and technologies. It aimed to bring the deprived sections of society into the banking network and ensured that the benefits of economic growth percolate to all levels.

- Banks were advised to ensure that every household has at least one bank account and service area bank in rural areas.

- $\quad$ All the unbanked blocks i.e. 91 in North East states and 38 in other states, totally 129 blocks were identified in the country in July 2009 and were provided with banking facilities by March 2012.

- A Common Unstructured Supplementary Service Data (USSD) platform for all banks and Telecom companies who wish to offer the facility of Mobile banking using USSD based mobile banking was organized through National Payment Corporation of India (NPCL). Basic banking facilities like money transfer, bill payments, balance enquiry, payment etc. on a simple GSM based mobile phone without the need to download application on a phone.

- All banks were advised to make available a basic banking 'no-frills' account either with 'nil' or very low minimum balances as well as charges that would make such accounts accessible to vast sections of population. 
- Banks were instructed to introduce a General Credit Card (GCC) facility up to `25,000 in rural and semiurban areas, which aims at providing credit card like facilities in rural areas with limited point-of-sale (POS) and limited automated teller machine (ATM) facilities, based on the assessment of income and cash.

- The KYC (know your customer) procedure for opening accounts was simplified for those accounts with balances not exceeding ` 50,000 and credit thereto not exceeding ` 100,000 in a year in order to facilitate people belonging to low income group in urban and rural areas face no difficulties in opening bank account.

- Domestic scheduled commercial banks (other than RRBs) are now free to open branches in towns and villages with less than 50,000 population and also ensure that at least one-third of such branch expansion happens in the under banked areas. In order to ensure fair pricing and enhanced access of the ATMs, RBI under its "Free ATM access policy" since April 01, 2009 ensures that no charges are payable for using other banks' ATM. However, banks can restrict the number of such free transactions to a maximum of five per month.

- The BCs (Business correspondent) were allowed to conduct banking business as agents of the banks at places other than the bank premises. The categories of entities that could act as BCs were also specified. The BFs (Business Facilitators) includes identification of borrowers, collection and preliminary processing of loan applications, creating awareness about bank products, education \& advice on managing money, debt counseling, processing and submission of application to banks, promotion of Self Help Groups/ Joint Liability Groups, post sanction monitoring, follow up for recovery etc, may be used for facilitation services for which approval of RBI is not required.

- Banks need to constitute Grievance Redressal Machinery within the bank for redressing complaints about services rendered by BFs /BCs and give wide publicity about it through electronic and print media. So, that the customers are comfortable and have confidence and reliability in the new system and trust in the operator.

- $\quad \mathrm{BC}$ is essential to outreach and educate people relating any to transaction to ensure that people are connected to and actively using payment system. In order to retain $\mathrm{BC}$, reasonable remuneration and incentive pay is required.

- There is a need for legislation from the Government making it mandatory to transfer all the social benefits through these accounts to make it operational. Once this is done the banking habit will start developing.

- Banks may devise an Off-Site Real Time Monitoring system, a mobile-based IT initiative, which uses a combination of GPS (Global Positioning System) and GPRS (General Packet Radio Services) technologies through cell phones for monitoring the BCs.

- Registration of a complaint through SMS against BC should be structured to go to the concerned officials under that jurisdiction, time line for redressal, should also be fixed. This will build confidence in the business model and make it a success.

- Aadhaar is a 12-digit unique number issued by the Unique Identification Authority of India (UIDAI) to all Indian residents after collecting and verifying their demographic (e.g., location) and biometric (e.g., fingerprint, iris) data. The information in the database will be used only for authentication purpose. If anyone seeks to authenticate the identity of another person using the Aadhaar database, he/she will only receive a response in the affirmative or negative way.

- State Governments are actively looking at making pension payments as also disbursals under Rural Employment Generation Program using smart cards linked bank accounts. Smart card provides biometric authentication, which would help in reducing frauds and ensure identity of customers. Such cards can also hold all transaction details on the card. In order to popularize smart cards, all agricultural short term loans and payment of social security schemes are to be dispensed through Smart Cards.

\section{Models used for financial inclusion:-}

Lead Bank System:- Under this scheme, all villages having population above 2000 are to be provided with access to financial services by March 2012 and those having population below 2000 are to be covered in an integrated manner. Public and private sector banks have been assigned to act as a consortium leader to coordinate the efforts of banks in the district in the matters like branch expansion and credit planning.

Correspondent banking:- Intermediaries such as Business Facilitators (BFs) or Business Correspondents (BCs) are permitted by Reserve Bank of India for providing banking and financial services. The BCs act as agents of the banks at places other than the bank premises and for this purpose, banks were allowed to utilize the services of NGOs, micro-finance institutions and other civil society organizations 
Microfinance Model:- The model consists of Microfinance system in India including Self Help Groups. In India, there are a variety of micro-credit models operating which makes it the world's best laboratory for micro finance.

\section{Role of Technology:-}

Technology plays an important role in reducing operating cost of providing banking services in rural areas and to low income groups. Three broad types of technologies such as (i) low-cost cell phones; (ii) ATMs and other point of sale devices; and (iii) smart plastic cards to drive the growth of financial services. Technology blended with appropriate business model and policy which would be affordable, viable and sustainable would facilitate access to finance for the population at large.

The centralised data processing system and the non-conventional methods based on computer systems do not require uninterrupted electric supply and radio frequency network can considerably reduce the cost of extending financial services. Branchless banking and establishment of new partnerships between financial service providers and a range of other service providers is feasible with technology to provide services in remote areas and low-population areas.

Mobile banking services are revolutionising micro-finance services in a number of countries (Asian Development Bank, 2007) which is used for performing balance checks, account transactions and payments. The extent to which technology will be integrated into the financial service industry depends on supportive government policies and the quality of infrastructure, particularly in rural areas.

Banks in India have initiated pilot projects utilising smart cards and biometric methods for identifying customers to increase their outreach. State Bank of India initiated a project called the SBI Tiny Card Accounts (SBITCAs) recently in Aizwal which is a combination of 'no-frills' account and BCs/BFs model. It is operated through new generation mobile phones based on near-field communication (NFC) technology, enhanced with fingerprint recognition software and attached to receipt printer. There are various advantages of the card, such as microsavings (SBI-tiny no-frills pre-paid account), cash deposits and withdrawal, micro-credit, money transfer (accountto-account within the system), micro-insurance, cashless payments to merchants, SHG savings-cum-credit accounts and attendance systems, disbursements of Government benefits like the national rural employment guarantee scheme, for equated monthly instalments (EMIs), utility payments, coupons, vouchers and tickets, loyalty points, automatic fare collection systems, portable and fixed positions for front-end devices.

The presence of Television in all households has become one of the most cost effective modes to disseminate information across the country. Banks may explore the possibility of making use of cable network to extend banking services to remote rural areas and this can be used as non-branch service delivery channel.

Table 1:- Status of financial inclusion in Tamil Nadu - District Scores (bank-led) Inclusix scores.

\begin{tabular}{|l|l|l|l|l|l|}
\hline State & District & \multicolumn{2}{|l|}{ CRIL Inclusix Scores } & \multicolumn{2}{l|}{} \\
& & $\mathbf{2 0 1 2}$ & $\mathbf{2 0 1 1}$ \\
\hline Tamil Nadu & Ariyalur & 62.9 & 55.2 & 49.5 & 46.4 \\
\hline Tamil Nadu & Chennai & 82.6 & 82.3 & 82.0 & 82.8 \\
\hline Tamil Nadu & Coimbatore & 95.4 & 89.7 & 83.4 & 75.9 \\
\hline Tamil Nadu & Cuddalore & 63.6 & 59.7 & 55.6 & 54.6 \\
\hline Tamil Nadu & Dharmpuri & 54.4 & 50.2 & 46.4 & 44.4 \\
\hline Tamil Nadu & Dindigul & 69.8 & 63.2 & 58.8 & 55.6 \\
\hline Tamil Nadu & Erode & 75.3 & 71.7 & 68.3 & 63.4 \\
\hline Tamil Nadu & Kancheepuram & 74.4 & 62.1 & 59.6 & 55.7 \\
\hline Tamil Nadu & Kanyakumari & 77.7 & 73.2 & 69.5 & 70.5 \\
\hline Tamil Nadu & Karur & 73.6 & 69.4 & 66.3 & 61,6 \\
\hline Tamil Nadu & Krishnagiri & 61.9 & 57.2 & 52.4 & 50.3 \\
\hline Tamil Nadu & Madurai & 75.5 & 71.0 & 68.7 & 63.8 \\
\hline Tamil Nadu & Nagapattinam & 68.5 & 61.8 & 56.9 & 54.7 \\
\hline Tamil Nadu & Namakkal & 72.7 & 64.5 & 56.6 & 53.0 \\
\hline Tamil Nadu & Nilgiris & 82.0 & 76.0 & 71.7 & 71.3 \\
\hline Tamil Nadu & Permabalur & 73.3 & 68.0 & 63.7 & 57.9 \\
\hline Tamil Nadu & Pudukkottai & 66.6 & 61.2 & 56.0 & 53.1 \\
\hline
\end{tabular}




\begin{tabular}{|l|l|l|l|l|l|}
\hline Tamil Nadu & Ramanathapuram & 65.8 & 61.3 & 57.0 & 53.0 \\
\hline Tamil Nadu & Salem & 63.4 & 57.0 & 50.7 & 46.7 \\
\hline Tamil Nadu & Sivaganga & 82.3 & 77.0 & 74.8 & 70.8 \\
\hline Tamil Nadu & Thanjavur & 71.1 & 65.2 & 61.1 & 58.6 \\
\hline Tamil Nadu & Theni & 71.9 & 65.0 & 60.7 & 56.3 \\
\hline Tamil Nadu & Thiruvallur & 55.8 & 52.5 & 48.4 & 46.3 \\
\hline Tamil Nadu & Thruvarur & 70.7 & 64.5 & 57.4 & 56.1 \\
\hline Tamil Nadu & Thiruchirapalli & 78.4 & 74.5 & 70.5 & 65.3 \\
\hline Tamil Nadu & Tirunelvali & 72.3 & 69.4 & 64.4 & 61.2 \\
\hline Tamil Nadu & Tiruppur & 67.0 & 62.9 & 53.8 & 49.1 \\
\hline Tamil Nadu & Tiruvannamalai & 55.3 & 49.7 & 45.3 & 44.3 \\
\hline Tamil Nadu & Toothukudi & 74.5 & 71.5 & 66.5 & 61.9 \\
\hline Tamil Nadu & Vellur & 59.5 & 53.7 & 49.6 & 47.0 \\
\hline Tamil Nadu & Villupuram & 54.2 & 48.1 & 45.1 & 44.1 \\
\hline Tamil Nadu & Virudhunagar & 71.3 & 65.0 & 59.4 & 56.5 \\
\hline Sarce Cril
\end{tabular}

Source: Crisil Inclusix-An index to measure India's progress on financial inclusion, Volume - III | June 2015

According to the index of Crisil given in the above table, among the various districts in Tamil Nadu, Coimbatore is the top scorer of financial inclusion and next comes Chennai in all four years. During the year 2013, Coimbatore represents 95.4 and Chennai with 82.6, as well as Nilgiris and sivaganga are nearer to Chennai's score with 82.0 and 82.3 .

According to the Crisil Inclusix, the districts which have scored more than 55 are considered to be on high level of financial inclusion. During the fiscal year 2013, Tamil Nadu was in the top 3 position with a CRISIL Inclusix score of 79.2. The reason behind this achievement was that more than 1 crore new savings accounts were opened in the state and the linkage programmes by MFIs and self-group bank ensured a very high CP score of 97.

CRISIL Inclusix is the first comprehensive measure of financial inclusion in India in the form of an index. It is a comparative index that has a scale of 0 to 100 and combines three very important parameters of basic financial services. The first parameter is the branch penetration (BP), second is the deposit penetration (DP) and finally credit penetration (CP). With these parameters, CRISIL evaluates financial inclusion at the national, regional, state and district level. A score of 100 indicates the ideal state for each of the three parameters according to CRISIL Inclusix.

\section{Conclusion:-}

The Government, RBI and banks mostly emphasized to open more accounts which would not help furthering the cause of financial inclusion. Financial inclusion requires continuous efforts that would become costly for the banks who aim at profit making organistions.

The entire emphasis of the Government, RBI and banks is to open more accounts. Since banks are profit making organizations, the Government should reimburse the cost incurred under financial inclusion which requires consistent efforts. Doorstep inclusion programmes are provided as an incentive to make the other people join.

The reason for slow progress in financial inclusion is absence of reach and coverage by banks. This sluggishness can be bridged through the use of information and communication technology. In spite of provision of uncomplicated, small, affordable products to the low income families to bring into the formal financial sector, there are limitations to reach directly to the low income consumers. The use of technologies and using economies of scale will bring a win - win position for both banks and customers. Mobile banking and Micro ATM offers one of the most promising options for providing financial services to the unbanked population.

Government's priority is financial inclusion and the extension of financial services to every citizen of the country. The goal of financial inclusion can be achieved with the help of technology. The enrolment to UID and UID enabled bank account will be a supportive system in the entire process of financial inclusion plan. 


\section{Reference:-}

1. Asian Development Bank. 2007. "Low Income Households' Access to Financial Services - International Experience, Measures for Improvement, and the Future.” EAsRD Special Studies, October.

2. All Banking solution.com

3. CRISIL (2013), "Inclusix Financial Inclusion Index", June.

4. 4. International journal of marketing, financial services and management research: Financial inclusion in India: An analysis ;Dr.Anurag B.Singh , Priyanka Tandon

5. Mohan, R. (2008), 'Economic growth, financial deepening, and financial inclusion', in M. Sharma (ed.), Dynamics of Indian Banking: Views and Vistas, New Delhi: Atlantic, pp. 92-120.

6. Oya Pinar Ardic Maximilien Heimann Nataliya Mylenko. (2011). Access to Financial Services and the Financial Inclusion Agenda Around the World, The World Bank, pp 1-17. 7. Reserve Bank of India, Publication, September 8, 2008

7. Reserve Bank of India, Annual Report 2010

8. 9.RBI (2014a), "Report on comprehensive financial services for small businesses and low Income households" (Chairman: Dr. N. Mor). 